\title{
BACTERIOLOGICAL ANALYSIS OF WATER SAMPLES FROM TSUNAMI HIT COASTAL AREAS OF KANYAKUMARI DISTRICT, TAMIL NADU
}

\author{
*P Rajendran, S Murugan, S Raju, T Sundararaj, BM Kanthesh, EV Reddy
}

\begin{abstract}
Water borne diseases such as cholera, enteric fever and dysentery were expected after the tsunami, which hit the coastal areas of Kanyakumari district, Tamil Nadu. In the present study 151 drinking water sources were collected from the tsunami affected villages and relief shelters and tested for coliforms and pathogens. Nine well water samples were also collected for specific bacteriological analysis. Presence of coliforms was detected in 56 (37\%) water samples. One isolate each of Salmonella Paratyphi B and NAG Vibrio were isolated from two well water samples. There was no report of acute diarroeal diseases or typhoid illness during the post tsunami period monitored by a field microbiology laboratory for a month.
\end{abstract}

Key words: Tsunami, drinking water contamination, MPN, bacteriological analysis

The tsunami that devastated Indian Ocean region on December 26, 2004, represents the greatest natural disaster of our times ${ }^{1}$ which killed more than 250000 people in 13 countries $^{2}$ and over five million have been left homeless in South Asia including India. ${ }^{3}$

The biggest challenge of India's health establishment after the tsunami was directed towards sustaining disease surveillance to prevent epidemics in the affected areas. ${ }^{4}$ Tamilnadu was one of the worst affected states in India, which reported the highest number of deaths and displaced people. Basic services such as clean water and sanitation were severely affected in the coastal areas by tsunami. Survivors were under serious threat of disease outbreaks as a result of damaged water and sanitation systems, seawater contamination and the congested and crowded conditions of the displaced. There was an immediate increased risk of waterborne diseases like cholera, typhoid fever, shigellosis and hepatitis $\mathrm{A}$ and $\mathrm{E}$, which are related to unsafe drinking water and inadequate sanitation. ${ }^{5}$

A tsunami creates a surge of ocean water that can sometimes engulf large geographic areas. As the ocean water comes ashore, drinking water sources can become submerged and potentially contaminated with microorganisms. If water containing disease-causing microorganisms is ingested, it may cause immediate, life threatening health problems such as acute diarroeal diseases, cholera and other serious infections.

*Corresponding author (email: <rajendranparam@hotmail.com>) Department of Microbiology (PR, TS, BMK, EVR), Dr. ALM PGIBMS, University of Madras, Taramani, Chennai - 600 013, and Department of Public Health and Preventive Medicine (SR, SM), Anna Salai, Chennai - 600 006, Tamil Nadu, India

Received : 10-06-05

Accepted : 15-01-06
In Tamilnadu, immediately after the disaster, the department of public health and preventive medicine mobilized epidemiologists, medical officers, paramedical staff and health workers from various parts of the state to the affected coastal districts to take care of health related issues of the coastal area population afflicted by the tsunami.

As an integral part of epidemic preparedness, the microbiologists deputed from the Department of Public Health and Preventive Medicine, Chennai, established a field microbiology laboratory at Kanyakumari district, Tamilnadu. In this report, various drinking water sources were analysed for bacteriological contamination due to tsunami along the coastal areas and provision of safe drinking water to large displacement centers (relief shelters) to prevent waterborne diseases.

\section{Materials and Methods}

One hundred and fifty-one water samples from various drinking water sources from the tsunami affected villages of Kanyakumari district, Tamil Nadu, including the ones damaged due to tsunami before the implementation of clean-up and decontamination procedures by the local administration and the water supply to the 54 relief shelters, were collected in sterile plastic containers from December 28, 2004 onwards for overall analysis of coliform count and pathogens like Salmonella and Vibrio by commercial rapid water testing kits. In addition, nine well water samples from Colachel coastal area were transported in dry ice to the department of microbiology, Dr. ALM postgraduate institute of basic medical sciences, Chennai, for specific bacteriological analysis.

\section{Coliform test (presence or absence)}

The presence or absence of Coliform bacteria $^{6}$ from 
drinking water sources were detected using the commercially available PA Coliform test kit, HiMedia laboratories, India. A positive coliform test indicates feacal contamination in the water sample.

\section{Test for Escherichia coli}

Rapid detection and confirmation of Escherichia coli based on enzyme-substrate reaction was performed using the commercially available HiSelective E.coli test kit, HiMedia Laboratories, India. $^{7}$

\section{Test for Salmonella and Vibrio species}

Rapid detection of Salmonella species and Vibrio species were tested by commercially available Rapid HiWater Test kits, HiMedia Laboratories, India. ${ }^{8}$ This test also detects E.coli and Citrobacter species.

\section{Test for culture and isolation}

All the nine samples received on dry ice were tested for MPN for coliforms and culture on nutrient agar, MacConkey's agar and blood agar for isolation and identification of specific pathogens and the bacterial isolates were confirmed by biochemical tests.

\section{Results}

A total of 151 water samples from various sources from tsunami hit coastal areas of Kanyakumari district, Tamil Nadu, were tested for the presence of coliforms and pathogens by rapid water testing kits. The test results showed the presence of coliforms in $56(37 \%)$ water samples but the pathogens like Salmonella spp. and Vibrio spp. were not detected by the rapid detection kits (Table 1).

The bacteriological analysis of drinking water samples

Table 1: Water sample analysis by rapid water test kits in the coastal areas of Kanyakumari district after December 2004 tsunami

\begin{tabular}{lccc}
\hline $\begin{array}{l}\text { Type of } \\
\text { water sample }\end{array}$ & $\begin{array}{c}\text { Total no. } \\
\text { tested }\end{array}$ & $\begin{array}{c}\text { Positive } \\
\text { for coliforms }\end{array}$ & $\%$ \\
\hline Over head tank & 43 & 17 & 39.5 \\
Sintex plastic tank & 29 & 9 & 31 \\
Packed drinking water & 25 & - & - \\
Bore well & 23 & 14 & 60.9 \\
Public well & 17 & 13 & 76.5 \\
Public fountain & 9 & 1 & 11 \\
Sump & 1 & 1 & \\
Reservoir & 1 & 1 & \\
Filter house & 1 & - & - \\
Bottle & 1 & - & - \\
Aqua guard & 1 & - & - \\
Total & $\mathbf{1 5 1}$ & $\mathbf{5 6}$ & $\mathbf{3 7 . 0 8}$ \\
\hline
\end{tabular}

revealed that 13 out of $17(76.5 \%)$ public well water samples, 14 out of $23(60.9 \%)$ bore well samples, 17 out of $43(39.5 \%)$ over head tank samples and nine out of $29(31 \%)$ plastic storage tanks were contaminated with coliforms.

Out of the nine well-water samples from Colachel coastal area tested for specific pathogens, one each of Salmonella Paratyphi B and NAG Vibrio were isolated from two different well water samples. Other bacterial species isolated from well water samples were Aeromonas hydrophila, Pseudomonas aeruginosa, Escherichia coli, Citrobacter freundii and Enterococci. Interestingly a fungus Penicillium oxalicum was also isolated from the well water, which was also positive for Salmonella Paratyphi B (Table 2).

\section{Discussion}

The tsunami that struck 13 countries in South Asia on the morning of December 26, 2004, resulted in a natural disaster of apocalyptic proportions. The sheer scope and severity of destruction prompted extraordinary international attention and support for survivors on the coastal rims and the islands in the Bay of Bengal and the Indian Ocean.

The short-term public health emergency needs of the surviving population were enormous, of which provision of safe drinking water was of paramount importance to persons who live in relief shelters. It was cautioned that the number of causalities might double with the spread of communicable diseases in tsunami hit coastal areas. ${ }^{9}$

However, the present study showed contamination in 56 (37\%) drinking water sources, majority of which were public wells and bore wells. Although one each of Salmonella Paratyphi B and NAG Vibrio was isolated from well water samples subsequently there was no report of acute diarrhoeal or typhoid illness from the Colachel area of Kanyakumari district during post tsunami period, which were monitored for about a month by the public health microbiology laboratory. The public health authorities provided chlorinated drinking water to the displaced population through plastic tanks and potable water through plastic packs. In addition, the coastal area population was advised by the health authorities, not to use well water for drinking purpose which were flooded with sea water due to tsunami. These wells will remain unsafe for some more time and in future the local authorities would probably drain all the wells and allow to replenish again with natural water from ducts.

It is interesting to note that, the literature on disasters also indicates that epidemics of communicable diseases do not always occur after large-scale floods. In the past three decades, epidemics of water borne illness such as cholera and shigellosis have been uncommon after floods and natural disasters but they are quite common in large displacement centers and refugee camps. ${ }^{10}$ 
Table 2: Bacterial isolates from well water samples at Colachel area after December 2004 tsunami

\begin{tabular}{|c|c|c|c|c|}
\hline \multirow[t]{2}{*}{ Location } & \multirow[t]{2}{*}{ Organisms } & \multicolumn{3}{|c|}{ MPN result } \\
\hline & & $10 \mathrm{ml}$ & $1 \mathrm{ml}$ & $0.1 \mathrm{ml}$ \\
\hline Mallukka well, Asad nagar, Pandakasalaipuram & Aeromonas hydrophila & 0 & 0 & 0 \\
\hline Municipal well, Kotilpadu Road & $\begin{array}{l}\text { Pseudomonas putrefaciens, Aeromonas } \\
\text { hydrophila ,Salmonella para } \\
\text { typhi B, Penicillium oxalicum }\end{array}$ & 5 & 5 & 5 \\
\hline Well, Akkarai Pallivasal & $\begin{array}{l}\text { Aeromonas hydrophila, Pseudomonas } \\
\text { aeruginosa, Pseudomonas } \\
\text { putrefaciens, Citrobacter freundii }\end{array}$ & 5 & 5 & 5 \\
\hline Well, Akkarai Pallivasal & Pseudomonas putrefaciens & 1 & 0 & 0 \\
\hline Colachel Beach & $\begin{array}{l}\text { Pseudomonas putrefaciens } \\
\text { Aeromonas hydrophilia }\end{array}$ & 0 & 0 & 0 \\
\hline Colachel Beach & E.coli, Vibrio Group (NAG) & 0 & 0 & 0 \\
\hline TWAD Board well I, Kottilpadu & Enterococci (Streptococcus faecalis) & 0 & 0 & 0 \\
\hline TWAD Board Well II, Kottilpadu & Pseudomonas aeruginosa & 0 & 0 & 0 \\
\hline TWAD Board Well III, Kottilpadu & Pseudomonas aeruginosa & 0 & 0 & 0 \\
\hline
\end{tabular}

\section{References}

1. Silove D, Zwi AB. Translating compassion into psychosocial aid after the Tsunami. The Lancet 2005;365:269-71.

2. McCurry J. Cleaning up after the tsunamis. The Lancet 2005;365:835-6.

3. Frist WH. Recovering from the Tsunami. $N$ Engl J Med 2005;352:438.

4. Chatterjee P. India's health workers rise to the occasion. The Lancet 2005;365:283.

5. Moszynshi P. Disease threatens millions in the wake of Tsunami. BMJ 2005;330:59.

6. Greenberg AE, Trussel RR, Clesceri LS (Eds). Standard methods for the examination of water and waste water, $16^{\text {th }}$ ed. APHA: Washington, DC; 1965.

7. Hansen W, Yoorassawsky E. Detection of beta-glucuronidase in lactose-fermenting members of the family Enterobacteriaceae and its presence in bacterial urine cultures. J Clin Microbiol 1984;20:1177-9.

8. Manja KS, Maurya MS, Rao KM. Bull World Health Organ 1982;60:797-801.

9. Rooyen MV, Leaning J. After the Tsunami - Facing the public health challenges. N Engl J Med 2005;352:435-8.

10. World Health Organization. Flooding and communicable disease fact sheet: Risk assessment and preventive measures. http:// www.who.int/hac/techguidance/ems/floods_cds/en/2005. 